\title{
Analysis of Association between Norepinephrine Transporter Gene Polymorphisms and Personality Traits of NEO-FFI in a Japanese Population
}

\author{
Shin Narita ${ }^{1}$, Kazuhiko Iwahashi ${ }^{1,2,3} \bowtie$, Kenta Nagahori', Maki Numajiri', \\ Eiji Yoshihara ${ }^{1}$, Nobuyo Ohtani ${ }^{4}$, and Jun Ishigooka ${ }^{3}$ \\ ${ }^{1}$ Laboratory of Neurophysiology, Graduate School of Environmental Health Sciences, Azabu University, Kanagawa, Japan \\ ${ }^{2}$ Health Administration Center, Azabu University, Kanagawa, Japan \\ ${ }^{3}$ Department of Neuropsychiatry, Tokyo Women's Medical University, Tokyo, Japan \\ ${ }^{4}$ Laboratory of Effective Animals for Human Health, Azabu University, Kanagawa, Japan
}

Objective Norepinephrine is an important chemical messenger that is involved in mood and stress in humans, and is reabsorbed by the norepinephrine transporter (NET). According to Cloninger's theory, the noradrenergic system mediates the personality trait of reward dependence. Thus far, although association studies on NET gene polymorphisms and Cloninger's personality traits have been reported, they yielded inconsistent results. Therefore, in the present study we investigated whether or not the 1287G/A, $-182 \mathrm{~T} / \mathrm{C}$ and $-3081 \mathrm{~A} / \mathrm{T}$ polymorphisms of the NET gene (SLC6A2) are associated with reward dependence-related traits, as assessed by the five-factor model.

Methods After written informed consent was obtained from participants, the three NET gene polymorphisms were analyzed by polymerase chain reaction (PCR)-restriction fragment length polymorphism (RFLP), and personality was assessed by the Neuroticism Extraversion Openness-Five Factor Inventory (NEO-FFI) in 270 Japanese university students.

Results A significant relation was found between the -3081A/T functional promoter polymorphism and NEO-FFI scores: those with the $\mathrm{T}$ allele exhibited a lower extraversion (E) score than those without the T allele (Mann-Whitney U-test: $\mathrm{z}=-3.861, \mathrm{p}<0.001$ ). However, there was no correlation between the other NET gene polymorphisms and E score, and no association with other dimensions and these three polymorphisms.

Conclusion We conclude that the -3081A/T functional polymorphism in the NET gene may affect the extraversion of reward dependence-related traits, as measured by NEO-FFI. However, we used only the shortened version of NEO-PI-R in this study. Further investigations are necessary using the full version of self-rating personality questionnaires.

Psychiatry Investig 2015;12(3):381-387

Key Words Norepinephrine transporter, Gene polymorphism, NEO-FFI, Personality.

\section{INTRODUCTION}

Norepinephrine is one of the catecholamines, and is important as a neurotransmitter in the sympathetic peripheral nervous system. ${ }^{1}$ Noradrenergic pathways support arousal, mood, attention and reaction to stress. ${ }^{2}$ The action of norepinephrine is controlled by norepinephrine binding proteins such as the

Received: May 20, 2014 Revised: September 17, 2014

Accepted: October 21, 2014 Available online: July 6, 2015

$\triangle$ Correspondence: Kazuhiko Iwahashi, MD, PhD

Health Administration Center, Azabu University, 1-17-71 Fuchinobe, Chuo-ku, Sagamihara-shi, Kanagawa 252-5201, Japan

Tel: +81 42769 1930, Fax: +81 42769 1930, E-mail: iwahashi@azabu-u.ac.jp

(c) This is an Open Access article distributed under the terms of the Creative Commons Attribution Non-Commercial License (http://creativecommons.org/licenses/by$\mathrm{nc} / 3.0$ ) which permits unrestricted non-commercial use, distribution, and reproduction in any medium, provided the original work is properly cited. norepinephrine transporter (NET) and adrenergic receptors, ${ }^{3}$ where norepinephrine reuptake is mainly performed by NET. NET is a monoamine transporter, i.e., a $\mathrm{Na}^{+} / \mathrm{Cl}^{-}$dependent neurotransmitter transporter, ${ }^{4}$ and it is a major target for the treatment of mood, anxiety and depression disorders. ${ }^{5}$ It has been shown that the NET knockout mice exhibit resistance to stress-induced depressive-like changes in behavior and brain neurotrophin expression. ${ }^{6}$ Furthermore, a recent psychophysiological study using positron emission tomography (PET) scan demonstrated that NET is involved in loss aversion, and individuals with lower thalamic NET showed stronger aversion to financial loss. ${ }^{7}$ These findings indicate the possibility that NET is related to human personality traits.

The human NET gene (SLC6A2) is located on chromosome $16 \mathrm{q} 12.2,{ }^{8}$ spanning approximately $45 \mathrm{~kb}$ and consisting of 14 
exons. ${ }^{9}$ A previous study has shown that some personality formation genes are implicated in susceptibility to various abnormal types of human behavior, including depression and attention deficit. ${ }^{10}$ Therefore, among the several known NET gene polymorphisms, we focused on the 1287G/A (rs5569), -182T/ $\mathrm{C}$ (rs2242446) and -3081A/T (rs28386840) polymorphisms, for which an association with psychiatric disorders such as depression and attention deficit hyperactivity disorder (ADHD) has been indicated. ${ }^{11-15}$ Stober et al. ${ }^{16}$ detected a highly polymorphic silent $1287 \mathrm{G} / \mathrm{A}$ polymorphism in the NET gene, which was located in exon 9. The $-182 \mathrm{~T} / \mathrm{C}$ polymorphism is located in the 5 flanking promoter region, ${ }^{17}$ and this region of the NET gene contains several cis-elements of importance for transcriptional activity. ${ }^{18}$ The $\mathrm{T}$ allele of the $-3081 \mathrm{~A} / \mathrm{T}$ polymorphism, comprising a single nucleotide change of $\mathrm{A}$ to $\mathrm{T}$ at -3081 upstream of the transcription initiation site of the human NET gene, significantly decreased the NET promoter function compared to the A allele, as reported by Kim et al. ${ }^{13}$

Thus far, association studies of the NET gene polymorphism and personality traits have been reported, but they yielded inconsistent results. ${ }^{19-24}$ Cloninger proposed that the three heritable dimensions of personality comprise novelty seeking, harm avoidance, and reward dependence, ${ }^{25}$ and in subsequent research, the Temperament and Character Inventory (TCI) was developed, which has four temperament dimensions (novelty seeking, harm avoidance, reward dependence, and persistence) and three character dimensions (self-directedness, cooperativeness, and self-transcendence), to assess the personality traits. ${ }^{26}$ Originally, according to Cloninger's theory, the three heritable dimensions of novelty seeking, harm avoidance, and reward dependence are related to different neurotransmitter systems, and the noradrenergic system mediates reward dependence of individuals. ${ }^{25,27}$ A previous study found a probable association between NET gene polymorphism and reward dependence. ${ }^{19}$ However, similar studies into NET gene polymorphisms have failed to find significant associations, and show a possible association with novelty seeking, but not reward dependence. ${ }^{20-24}$ In addition, several studies reported that in the five-factor model of personality, reward dependence primarily relates to extraversion. ${ }^{28,29}$ Therefore, if NET gene polymorphism contributes to the personality dimension of reward dependence, it might be associated with reward dependence-related traits in the five-factor model. All of these research findings are based on Cloninger's model. Hence, it is suggested that it is necessary to examine the relevance of NET gene polymorphism and the personality dimension of reward dependence using widely varying self-report personality questionnaires, thereby enabling more detailed analysis.

The Neuroticism Extraversion Openness-Five Factor Inventory (NEO-FFI) is one of the self-report questionnaires based on the five-factor model of personality that are used to examine the relationship between genes and personality. NEO-FFI is used to assess the five major dimensions of personality traits by means of a questionnaire comprising 60 items, it being a shortened version of the Revised NEO Personality Inventory (NEO-PI-R). The five dimensions are Neuroticism (N), Extraversion (E), Openness (O), Agreeableness (A) and Conscientiousness $(\mathrm{C}) .^{30}$ This questionnaire is superior in comprehensiveness, and enables assessment of the five personality dimensions needed for an efficient psychological profile of the individual. ${ }^{31}$

Therefore, in the present study, we investigated whether or not the $1287 \mathrm{G} / \mathrm{A},-182 \mathrm{~T} / \mathrm{C}$ and $-3081 \mathrm{~A} / \mathrm{T}$ polymorphisms of the NET gene are associated with reward dependence-related traits, as assessed by NEO-FFI.

\section{METHODS}

\section{Subjects}

The participants comprised 270 volunteers. In order to rule out confounding factors such as age and general intelligence level differences, all candidates for this research consisted of students in Azabu University, Japan. The mean age was 19.61 \pm 0.93 (mean \pm SD) years (male: $19.67 \pm 0.94$ years; female: $19.56 \pm$ 0.92 years). ${ }^{32}$ The subject's epidemiologic data is shown in Table 1 . The study was approved by the ethics committee of Azabu University, Japan. After obtaining written informed consent, blood samples were obtained from all the subjects. In addition, we performed the Japanese version of the NEO-FFI for all subjects. The validity and reliability of the Japanese version of the NEO-FFI have already been confirmed among the Japanese population. ${ }^{33}$

\section{DNA analysis}

We performed extraction and purification of genomic DNA by the phenol/chloroform method. Three NET gene polymorphisms were genotyped by means of polymerase chain reac-

Table 1. Subject's epidemiologic data

\begin{tabular}{lc}
\hline $\begin{array}{l}\text { Sex, male/female } \\
\text { Age }\end{array}$ & $117 / 153$ \\
NEO-FFI scores & $19.61 \pm 0.93(19-25)$ \\
Neuroticism & $30.18 \pm 7.90(6-47)$ \\
Extraversion & $25.16 \pm 7.14(5-44)$ \\
Openness & $28.87 \pm 5.59(13-46)$ \\
Agreeableness & $28.95 \pm 6.23(5-44)$ \\
Conscientiousness & $26.29 \pm 5.67(4-44)$ \\
\hline The figures on the table are showed as the mean \pm SD (range). NEO- \\
FFI: Neuroticism Extraversion Openness-Five Factor Inventory
\end{tabular}


tion (PCR)-restriction fragment length polymorphism (RFLP) according to the methods of Inoue et al. ${ }^{12,34}$ and Suzuki et al. ${ }^{22}$ Genomic DNA was amplified with the following primers: 1287 G/A (forward: 5'-TTCAGGGAGACCCTAATTCC-3', reverse: 5'-TTGACTTTATTGAAATGCGGC-3'), -182T/C (forward: 5'-CCATTTGGGGCAGGCGAAAGT-3', reverse: 5'-CGCTGACGGGACGCAGGGTTCCCAGCCAAG-3'), -3081A/T (forward: 5'-CCTGGGGCTCTGCTGTTAGC-3', reverse: 5'-CCTGGAAGCAATCGTTGGGG-3'). The PCR cycling conditions were: $10 \mathrm{~min}$ of denaturation at $95^{\circ} \mathrm{C}$, followed by 35 cycles of denaturation for $30 \mathrm{~s}$ at $95^{\circ} \mathrm{C}$, annealing for $30 \mathrm{~s}$ at $53^{\circ} \mathrm{C}(1287 \mathrm{G} / \mathrm{A}), 57^{\circ} \mathrm{C}(-182 \mathrm{~T} / \mathrm{C})$, or $60^{\circ} \mathrm{C}(-3081 \mathrm{~A} / \mathrm{T})$, and $\mathrm{ex}-$ tension for $30 \mathrm{~s}$ at $72^{\circ} \mathrm{C}$, followed by $7 \mathrm{~min}$ of extension at $72^{\circ} \mathrm{C}$. The PCR products (241 bp for $1287 \mathrm{G} / \mathrm{A}, 176 \mathrm{bp}$ for $-182 \mathrm{~T} / \mathrm{C}$, and $295 \mathrm{bp}$ for $-3081 \mathrm{~A} / \mathrm{T}$ ) were digested with a restrictive enzyme, Sau96 I, Sty I (New England Biolabs, Tokyo, Japan), or BsrS I (Promega Corp, Madison, USA), and the digested products were subjected to electrophoresis on $12.5 \%$ polyacrylamide gels and visualized using the ethidium bromide staining method. Genotypes were determined according to fragment sizes: $1287 \mathrm{G} / \mathrm{A}: \mathrm{G} / \mathrm{G}=113 \mathrm{bp}+76 \mathrm{bp}+31 \mathrm{bp}+21 \mathrm{bp}, \mathrm{G} / \mathrm{A}=113$ $b p+97 b p+76 b p+31 b p+21 b p, A / A=113 b p+97 b p+31 b p$; $-182 \mathrm{~T} / \mathrm{C}: \mathrm{T} / \mathrm{T}=176 \mathrm{bp}, \mathrm{T} / \mathrm{C}=176 \mathrm{bp}+146 \mathrm{bp}+30 \mathrm{bp}, \mathrm{C} / \mathrm{C}=146$ bp+30 bp, and -3081A/T: A/A=198 bp+97 bp, A/T=295 bp+ 198 bp+97 bp, T/T=295 bp (Figure 1).

\section{Statistical analyses}

The Hardy-Weinberg disequilibrium was assessed using a chi-square test. We compared the NEO-FFI scores among the
NET genotypes by performing statistical analysis using MannWhitney $U$-test. Because there were few subjects with the homozygotes for the minor allele, the subjects were divided into two groups regarding each polymorphism for statistical analyses, i.e., $\mathrm{G} / \mathrm{G}$ versus $\mathrm{G} / \mathrm{A}+\mathrm{A} / \mathrm{A}$ for $1287 \mathrm{G} / \mathrm{A}$ and $\mathrm{T} / \mathrm{T}$ versus $\mathrm{T} / \mathrm{C}+\mathrm{C} / \mathrm{C}$ for $-182 \mathrm{~T} / \mathrm{C}$. In the $-3081 \mathrm{~A} / \mathrm{T}$ polymorphism, as it was reported that the $\mathrm{T}$ allele causes decreased NET promoter function, ${ }^{13}$ we compared T-carriers with A/A homozygotes (A/ A versus A/T+T/T). A p-value was set at 0.05 (two-tailed). With five comparisons (Neuroticism, Extraversion, Openness, Agreeableness and Conscientiousness), a $\mathrm{p}$-value $<0.01$ $(0.05 / 5)$ was considered significant using the Bonferroni correction. Statistical analyses were performed using SPSS 12.0J for Windows.

\section{RESULTS}

The genotype frequencies of the NET gene polymorphisms were as follows: 1287G/A (G/G: 164, G/A: 89, A/A: 17); -182T/ C (T/T: 110, T/C: 128, C/C: 32) and -3081A/T (A/A: 76, A/T: 129, T/T: 65). The NET genotype distribution was in HardyWeinberg equilibrium (1287G/A: $\chi^{2}(1)=1.071, \mathrm{p}=0.301 ;-182 \mathrm{~T} /$ $\mathrm{C}: \chi^{2}(1)=0.321, \mathrm{p}=0.571$; and $\left.-3081 \mathrm{~A} / \mathrm{T}: \chi^{2}(1)=0.496, \mathrm{p}=0.481\right)$. No gender difference among NET genotypes were detected (1287G/A: $\chi^{2}(2)=1.591, \mathrm{p}=0.451 ;-182 \mathrm{~T} / \mathrm{C}: \chi^{2}(2)=0.168, \mathrm{p}=$ 0.919; and $\left.-3081 \mathrm{~A} / \mathrm{T}: \chi^{2}(2)=0.393, \mathrm{p}=0.821\right)$.

The NEO-FFI scores in university students grouped by NET gene polymorphisms are shown in Table 2 and Figure 2 . There was no significant effect of the $1287 \mathrm{G} / \mathrm{A}$ on the five dimension

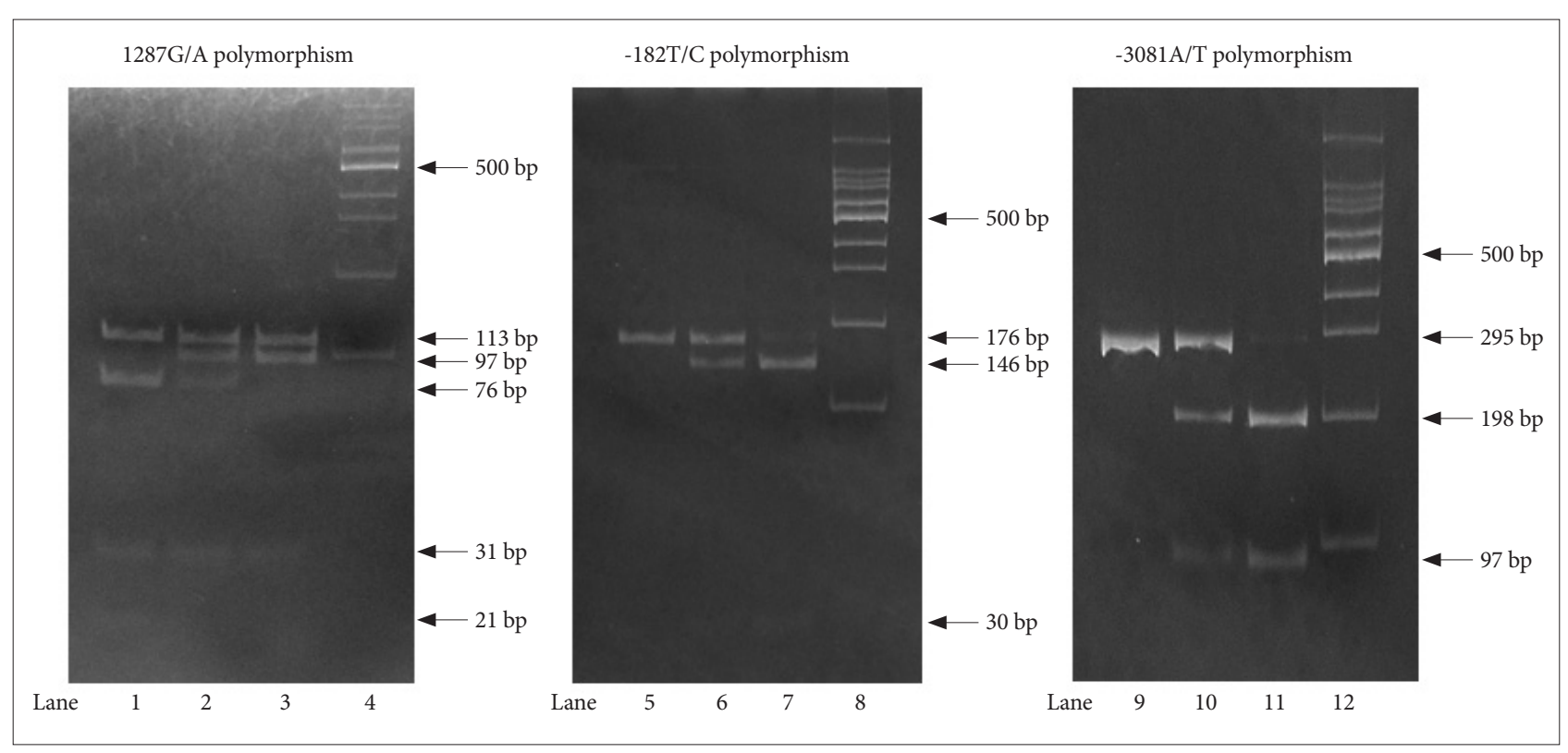

Figure 1. Representative results for the norepinephrine transporter gene polymorphisms with the PCR-RFLP method. Lane 1 is a G/G type. Lane 2 is a G/A type. Lane 3 is a A/A type. Lane 5 is a T/T type. Lane 6 is a T/C type. Lane 7 is a C/C type. Lane 9 is a T/T type. Lane 10 is a ATt type. Lane 11 is a A/A type. Lane 4, 8, and 12 are 100 bp DNA Ladder. PCR-RFLP: polymerase chain reaction-restriction fragment length polymorphism. 
Table 2. NEO-FFI scores in Japanese subjects grouped by the norepinephrine transporter gene polymorphisms

\begin{tabular}{rlcccccc}
\hline \multicolumn{1}{c}{ SNP } & \multicolumn{1}{c}{ Genotype } & $\mathrm{n}$ & $\mathrm{N}$ & $\mathrm{E}$ & $\mathrm{O}$ & $\mathrm{A}$ & $\mathrm{C}$ \\
\hline $1287 \mathrm{G} / \mathrm{A}$ & $\mathrm{G} / \mathrm{G}$ & 164 & $29.55 \pm 8.14$ & $25.51 \pm 6.62$ & $28.66 \pm 5.45$ & $29.22 \pm 5.80$ & $26.32 \pm 5.60$ \\
& $\mathrm{G} / \mathrm{A}+\mathrm{A} / \mathrm{A}$ & 106 & $31.15 \pm 7.46$ & $24.62 \pm 7.88$ & $29.19 \pm 5.82$ & $28.54 \pm 6.83$ & $26.24 \pm 5.79$ \\
& $\mathrm{~T} / \mathrm{T}$ & 110 & $29.89 \pm 8.36$ & $25.70 \pm 6.24$ & $29.19 \pm 6.05$ & $29.48 \pm 6.33$ & $25.73 \pm 6.03$ \\
$-182 \mathrm{~T} / \mathrm{C}$ & $\mathrm{T} / \mathrm{C}+\mathrm{C} / \mathrm{C}$ & 160 & $30.37 \pm 7.59$ & $24.79 \pm 7.70$ & $28.64 \pm 5.26$ & $28.59 \pm 6.15$ & $26.67 \pm 5.39$ \\
& $\mathrm{~A} / \mathrm{A}$ & 76 & $28.78 \pm 8.43$ & $27.74 \pm 6.36$ & $29.64 \pm 5.99$ & $29.91 \pm 5.86$ & $27.14 \pm 5.30$ \\
$-3081 \mathrm{~A} / \mathrm{T}$ & $\mathrm{A} / \mathrm{T}+\mathrm{T} / \mathrm{T}$ & 194 & $30.73 \pm 7.64$ & $24.15 \pm 7.19^{*}$ & $28.56 \pm 5.42$ & $28.58 \pm 6.34$ & $25.95 \pm 5.78$ \\
& & &
\end{tabular}

${ }^{*} \mathrm{p}<0.001$, significantly lower scores compared with A/A genotype (Mann-Whitney U-test). NEO-FFI scores are showed as the mean \pm SD. NEOFFI: Neuroticism Extraversion Openness-Five Factor Inventory, SNP: single nucleotide polymorphism, N: neuroticism, E: extraversion, O: openness, A: agreeableness, C: conscientiousness

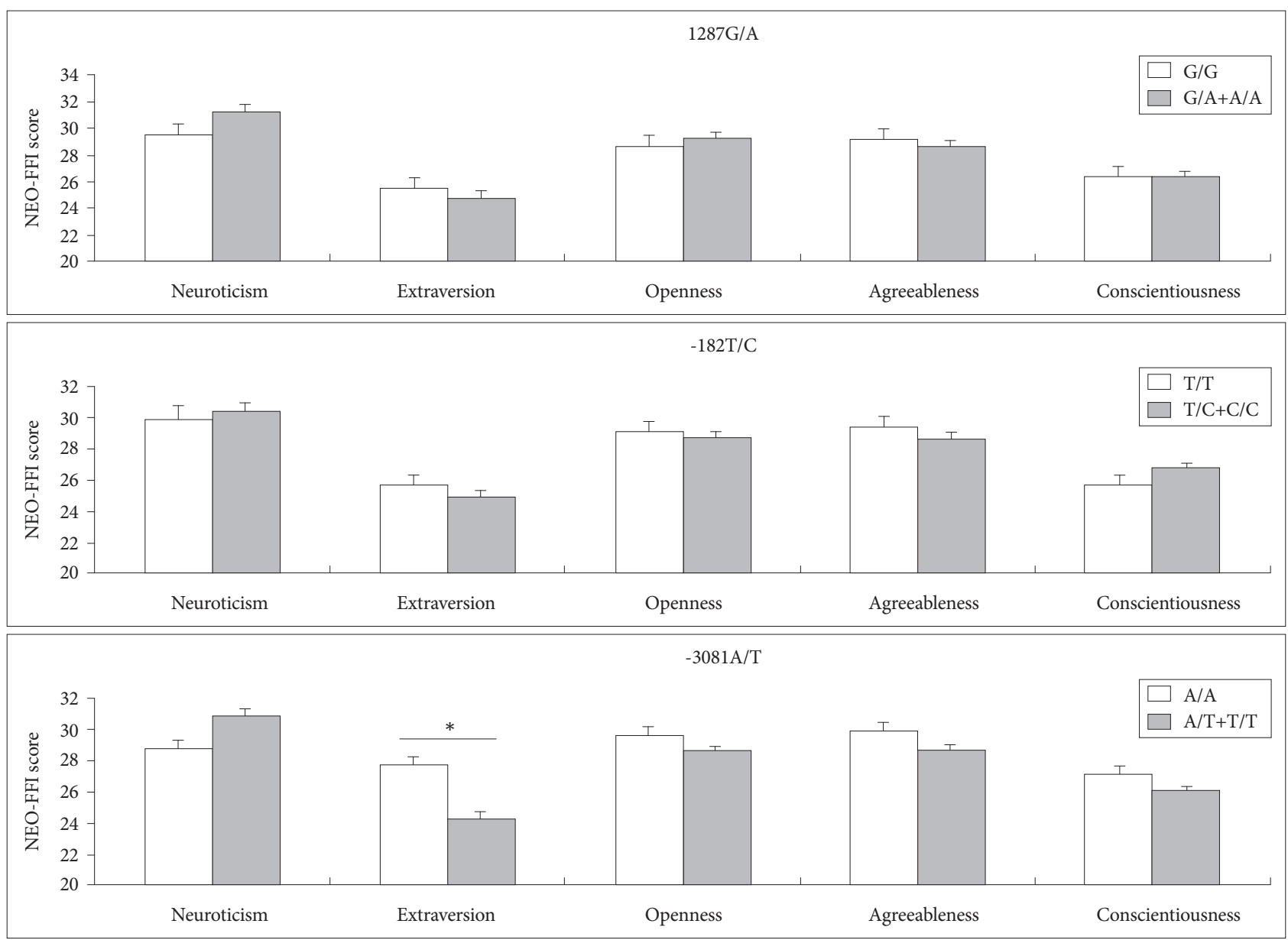

Figure 2. Effects of the norepinephrine transporter gene polymorphisms on the NEO-FFI scores. ${ }^{*} p<0.001$, the scores of extraversion were significantly different between the subjects with and without T allele (Mann-Whitney U-test). NEO-FFI: Neuroticism Extraversion OpennessFive Factor Inventory.

scores of NEO-FFI (N: $\mathrm{p}=0.081, \mathrm{E}: \mathrm{p}=0.622, \mathrm{O}: \mathrm{p}=0.352, \mathrm{~A}: \mathrm{p}=$ 0.682 , and $\mathrm{C}: \mathrm{p}=0.911)$. Furthermore, there was no significant effect of the $-182 \mathrm{~T} / \mathrm{C}$ on the five dimension scores of NEO-FFI $(\mathrm{N}: \mathrm{p}=0.638, \mathrm{E}: \mathrm{p}=0.258, \mathrm{O}: \mathrm{p}=0.222, \mathrm{~A}: \mathrm{p}=0.368$, and $\mathrm{C}: \mathrm{p}=$ $0.261)$. On the other hand, there was a significant association with extraversion among genotypes of $-3081 \mathrm{~A} / \mathrm{T}$, and the $\mathrm{A} /$ $\mathrm{T}+\mathrm{T} / \mathrm{T}$ genotypes (with $\mathrm{T}$ allele) had significantly lower scores than the $\mathrm{A} / \mathrm{A}$ genotype (without $\mathrm{T}$ allele) $(\mathrm{z}=-3.861, \mathrm{p}<0.001)$.
However, no significant associations were observed with the other four dimension scores ( $\mathrm{N}: \mathrm{p}=0.061, \mathrm{O}: \mathrm{p}=0.143, \mathrm{~A}: \mathrm{p}=$ 0.168 , and $\mathrm{C}: \mathrm{p}=0.128$ ).

\section{DISCUSSION}

It is possible that a norepinephrine transporter (NET) gene polymorphism is involved in the reward dependence-related 
personality trait. Although all previous research findings are based on Cloninger's model, it is thought necessary to examine the relationship between NET gene polymorphisms and the personality dimension of reward dependence, as assessed by not only Cloninger's model but also various other personality assessments, such as the five-factor model. In this study, we examined the relationship between three NET gene polymorphisms (1287G/A, -182T/C, and -3081A/T) and NEO-FFI, which is one of the self-report questionnaires based on the five-factor model of personality. The genotype and allele frequencies of the NET gene polymorphisms observed in this study were consistent with the genotype [1287G/A: $\chi^{2}(2)=$ $\left.0.695, \mathrm{p}=0.707 ;-182 \mathrm{~T} / \mathrm{C}: \chi^{2}(2)=2.274, \mathrm{p}=0.321\right]$ and allele $[1287$ $\mathrm{G} / \mathrm{A}: \chi^{2}(1)=0.061, \mathrm{p}=0.805 ;-182 \mathrm{~T} / \mathrm{C}: \chi^{2}(1)=1.029, \mathrm{p}=0.310$ ] frequencies observed in the HapMap (http://hapmap.ncbinlm. nih.gov/index.html.ja) Japanese population, respectively. Although the frequencies of the $-3081 \mathrm{~A} / \mathrm{T}$ polymorphism observed in the Japanese population have not been reported in the HapMap, data analysed in this study did not differ from other Japanese populations of healthy subjects [genotype: $\chi^{2}$ $(2)=1.994, p=0.369$; allele: $\left.\chi^{2}(1)=0.051, p=0.822\right] .{ }^{22}$

The main result of our study suggests that there is a significant relationship between the -3081A/T polymorphism and extraversion, and that individuals with the $\mathrm{A} / \mathrm{T}$ and $\mathrm{T} / \mathrm{T}$ genotype groups exhibited lower scores than ones with the A/A genotype group. It is worth noting that the $-3081 \mathrm{~A} / \mathrm{T}$ polymorphism is one of the functional variants. Kim et al. ${ }^{13}$ reported that the $\mathrm{T}$ allele of this polymorphism significantly decreases the NET promoter function compared with the A allele. Because of this function, the $-3081 \mathrm{~A} / \mathrm{T}$ polymorphism affects norepinephrine concentration in synaptic clefts in the brain, and consequently may also affect personality traits. Several studies investigated the relevance of Cloninger's model and the five-factor model as indicators of personality assessment, and indicated that there is a positive correlation between reward dependence in Cloninger's temperament dimensions and extraversion in the five personality dimensions. ${ }^{28,29}$ Meanwhile, low reward dependence has been related to high noradrenergic activity. ${ }^{25}$ Therefore, lower extraversion in subjects with the $\mathrm{A} / \mathrm{T}$ and $\mathrm{T} / \mathrm{T}$ genotypes may be explained by elevated extracellular levels of norepinephrine related to reduced functioning of the NET. Yamamoto and Novotney have described NET reuptake of not only norepinephrine but also dopamine in the medial prefrontal cortex (MPFC), and through this, norepinephrine terminals regulate extracellular dopamine concentrations. ${ }^{35}$ Furthermore, several previous studies suggest that because dopamine transporter activity is insufficient for the dopamine nerve terminals in the prefrontal cortex ${ }^{36}$ NET plays a role in dopamine reuptake instead. ${ }^{37}$ These findings indicate that the NET function influences dopaminergic activity. In- triguingly, several studies have reported that the extraversion personality trait shows a significant association with genetic polymorphisms in the dopaminergic system, e.g., dopamine D2 and dopamine D4 receptors. ${ }^{38-41}$ Therefore, the $-3081 \mathrm{~A} / \mathrm{T}$ functional polymorphism of the NET gene also affects the extracellular levels of dopamine, and consequently the dopaminergic system may be reflected in the personality trait of extraversion to which this polymorphism is related.

To our knowledge, research involving analysis of the relation of NET gene polymorphism and personality traits using NEO personality assessment as a questionnaire has not yet been reported in other research groups. Meanwhile, Stein et al. ${ }^{42}$ reported an association between polymorphisms in the genes of norepinephrine pathways and personality traits measured by NEO personality assessment. According to their report, the Ser$49 \mathrm{Gly}$ functional polymorphism in the $\beta_{1}$-adrenergic receptor gene (ADRB1) that may influences the resting heart rate is associated with extraversion. ${ }^{42}$ In addition, Miller et al. ${ }^{43}$ studied the relationship between major dimensions of personality and neurophysiological consequence in healthy adults, and reported that blood pressure and urinary levels of norepinephrine were associated with extraversion. Hypothetically, if noradrenergic activity is modulated by functional gene polymorphisms of norepinephrine pathways such as the $-3081 \mathrm{~A} / \mathrm{T}$ and Ser49Gly polymorphisms, extraversion might be linked to sympathetic nervous system activity.

In this study, we did not find a significant association between the 1287G/A and -182T/C NET gene polymorphisms and personality traits measured by NEO-FFI. The 1287G/A polymorphism is a silent mutation that does not affect any amino acid sequences, and it has no known important function. ${ }^{16}$ Meanwhile, Jonsson et al. ${ }^{44}$ reported that the $1287 \mathrm{G} / \mathrm{A}$ polymorphism was related to the main norepinephrine metabolite, i.e., 3-methoxy-4-hydroxyphenylglycol (MHPG), concentration in the cerebrospinal fluid (CSF) of healthy volunteers, and the CSF MHPG concentrations with the G/G genotype (without A allele) were higher than those with the G/A and A/A genotypes (with the A allele). In addition, it was reported that urinary levels of MHPG are significantly correlated with reward dependence in Cloninger's temperament dimensions in normal subjects. ${ }^{45}$ The $-182 \mathrm{~T} / \mathrm{C}$ polymorphism is located in a promoter region. ${ }^{17}$ Although the important function of the $-182 \mathrm{~T} / \mathrm{C}$ polymorphism is not clear, it is thought that this polymorphism located in the promoter region of the NET gene regulates transcription activity and gene expression. In fact, a previous study indicated that the 5 ' flanking promoter region of the NET gene comprises approximately $4.7 \mathrm{~kb}$ and an additional intron of $476 \mathrm{bp}$, and several important transcriptional elements containing enhancer sites reside in this intron in the region..$^{18}$ Furthermore, Ham et al. ${ }^{19}$ suggested that this poly- 
morphism is associated with reward dependence in the Korean population. From these observations, we hypothesized that these NET gene polymorphisms may also be related to reward dependence-related traits assessed by NEO-FFI, although there was no association between them in our study.

According to Cloninger's hypothesis, ${ }^{25,27}$ a previous study suggested that the NET gene polymorphism might be associated with reward dependence, ${ }^{19}$ but most studies did not replicate this finding. ${ }^{20-24}$ The different findings in these previous reports may be due to methodological difference such as sample size and statistical procedure. Incidentally, the genotype frequency of $1287 \mathrm{G} / \mathrm{A}$ polymorphism differs among races. For instance, in Polish people the G/G genotype accounts for $8 \%$, the G/A genotype $47 \%$, and the $\mathrm{A} / \mathrm{A}$ genotype $45 \%{ }^{21}{ }^{21}$ The genotype frequency in Polish people is thus different from that in the Japanese determined in this study $\left(\chi^{2}(2)=117.5, p<0.01\right)$. While, in Han Chinese people the G/G genotype accounts for $56 \%$, the G/A genotype $34 \%$, and the A/A genotype $10 \%{ }^{23}$ The genotype frequency in Han Chinese people is thus not different from that in the Japanese $\left(\chi^{2}(2)=2.343, p=0.310\right)$. Although both studies showed no relation between the 1287G/A gene polymorphism and personality traits, ${ }^{21,23}$ such a difference in genotype frequency among races illustrates a difficulty of the biological approach to elucidating personality formation factors. However, another way to clarify further the effect of the noradrenergic system on the personality dimension of reward dependence, is by utilizing various self-report personality questionnaires with different characteristics. ${ }^{23}$ In this study, we found that the NET gene polymorphism is significantly associated with extraversion of reward dependence-related factors, as assessed by NEO-FFI. Therefore, the NET might also be involved in reward dependence of individuals.

In conclusion, our study suggests that the $-3081 \mathrm{~A} / \mathrm{T}$ functional promoter polymorphism in the NET gene may affect extraversion, as assessed by NEO-FFI, in Japanese university students. If additional exploration of the NEO five personality dimensions reveals a significant relationship between extraversion and $-3081 \mathrm{~A} / \mathrm{T}$ polymorphism, this polymorphism might be useful as a biological marker in analyzing the genetics of psychiatric disorders, and may facilitate diagnosis in psychiatric assessment. However, although all samples in our study were from ostensibly healthy university students, this was not confirmed on the basis of clinical diagnosis by a psychiatrist. Therefore, in our findings, we did not control the possible confounding factor of the presence or absence of a mental disorder in individual participants. Additionally, to study the relationship between the NET gene polymorphism and personality traits, we used only the shortened version of NEO-PI-R in this study. Therefore, we will use the full NEO-PI-R in further studies, which will undoubtedly add further valuable insights into the implications of the association between NET gene polymorphism and personality traits.

\section{Acknowledgments}

This research was supported by a research project grant awarded by the Azabu University.

\section{REFERENCES}

1. Fritz JD, Jayanthi LD, Thoreson MA, Blakely RD. Cloning and chromosomal mapping of the murine norepinephrine transporter. J Neurochem 1998;70:2241-2251.

2. Hahn MK, Blakely RD. Monoamine transporter gene structure and polymorphisms in relation to psychiatric and other complex disorders. Pharmacogenomics J 2002;2:217-235.

3. Huang SY, Lu RB, Ma KH, Shy MJ, Lin WW. Norepinephrine transporter polymorphisms T-182C and G1287A are not associated with alcohol dependence and its clinical subgroups. Drug Alcohol Depend 2008; 92:20-26.

4. Uhl GR, Johnson PS. Neurotransmitter transporters: three important gene families for neuronal function. J Exp Biol 1994;196:229-236.

5. Torres GE, Gainetdinov RR, Caron MG. Plasma membrane monoamine transporters: structure, regulation and function. Nat Rev Neurosci 2003; 4:13-25.

6. Haenisch B, Bilkei-Gorzo A, Caron MG, Bonisch H. Knockout of the norepinephrine transporter and pharmacologically diverse antidepressants prevent behavioral and brain neurotrophin alterations in two chronic stress models of depression. J Neurochem 2009;111:403-416.

7. Takahashi H, Fujie S, Camerer C, Arakawa R, Takano H, Kodaka F, et al. Norepinephrine in the brain is associated with aversion to financial loss. Mol Psychiatry 2013;18:3-4.

8. Bruss M, Kunz J, Lingen B, Bonisch H. Chromosomal mapping of the human gene for the tricyclic antidepressant-sensitive noradrenaline transporter. Hum Genet 1993;91:278-280.

9. Porzgen P, Bonisch H, Bruss M. Molecular cloning and organization of the coding region of the human norepinephrine transporter gene. Biochem Biophys Res Commun 1995;215:1145-1150.

10. Ebstein RP, Benjamin J, Belmaker RH. Personality and polymorphisms of genes involved in aminergic neurotransmission. Eur J Pharmacol 2000; 410:205-214.

11. Hahn MK, Blackford JU, Haman K, Mazei-Robison M, English BA, Prasad HC, et al. Multivariate permutation analysis associates multiple polymorphisms with subphenotypes of major depression. Genes Brain Behav 2008;7:487-495.

12. Inoue K, Itoh K, Yoshida K, Shimizu T, Suzuki T. Positive association between T-182C polymorphism in the norepinephrine transporter gene and susceptibility to major depressive disorder in a japanese population. Neuropsychobiology 2004;50:301-304.

13. Kim CH, Hahn MK, Joung Y, Anderson SL, Steele AH, Mazei-Robinson MS, et al. A polymorphism in the norepinephrine transporter gene alters promoter activity and is associated with attention-deficit hyperactivity disorder. Proc Natl Acad Sci USA 2006;103:19164-19169.

14. Min W, Li T, Ma X, Li Z, Yu T, Gao D, et al. Monoamine transporter gene polymorphisms affect susceptibility to depression and predict antidepressant response. Psychopharmacology (Berl) 2009;205:409-417.

15. Yoshida K, Takahashi H, Higuchi H, Kamata M, Ito K, Sato K, et al. Prediction of antidepressant response to milnacipran by norepinephrine transporter gene polymorphisms. Am J Psychiatry 2004;161:1575-1580.

16. Stober G, Nothen MM, Porzgen P, Bruss M, Bonisch H, Knapp M, et al. Systematic search for variation in the human norepinephrine transporter gene: identification of five naturally occurring missense mutations and study of association with major psychiatric disorders. Am J Med Genet 1996;67:523-532.

17. Zill P, Engel R, Baghai TC, Juckel G, Frodl T, Muller-Siecheneder F, et 
al. Identification of a naturally occurring polymorphism in the promoter region of the norepinephrine transporter and analysis in major depression. Neuropsychopharmacology 2002;26:489-493.

18. Kim CH, Kim HS, Cubells JF, Kim KS. A previously undescribed intron and extensive 5 ' upstream sequence, but not Phox2a-mediated transactivation, are necessary for high level cell type-specific expression of the human norepinephrine transporter gene. J Biol Chem 1999;274:65076518.

19. Ham BJ, Choi MJ, Lee HJ, Kang RH, Lee MS. Reward dependence is related to norepinephrine transporter T-182C gene polymorphism in a Korean population. Psychiatr Genet 2005;15:145-147.

20. Lee BC, Yang JW, Lee SH, Kim SH, Joe SH, Jung IK, et al. An interaction between the norepinephrine transporter and monoamine oxidase A polymorphisms, and novelty-seeking personality traits in Korean females. Prog Neuropsychopharmacol Biol Psychiatry 2008;32:238-242.

21. Samochowiec J, Rybakowski F, Czerski P, Zakrzewska M, Stepien G, Pelka-Wysiecka J, et al. Polymorphisms in the dopamine, serotonin, and norepinephrine transporter genes and their relationship to temperamental dimensions measured by the Temperament and Character Inventory in healthy volunteers. Neuropsychobiology 2001;43:248-253.

22. Suzuki A, Matsumoto Y, Ishii G, Oshino S, Goto K, Otani K. No association between the $-3081 \mathrm{~A} / \mathrm{T}$ polymorphism in the norepinephrine transporter gene promoter and personality traits in healthy subjects. Neurosci Lett 2007;425:192-194.

23. Tsai SJ, Wang YC, Hong CJ. Norepinephrine transporter and alpha (2c) adrenoceptor allelic variants and personality factors. Am J Med Genet 2002;114:649-651

24. Yamano E, Isowa T, Nakano Y, Matsuda F, Hashimoto-Tamaoki T, Ohi$\mathrm{ra} \mathrm{H}$, et al. Association study between reward dependence temperament and a polymorphism in the phenylethanolamine $\mathrm{N}$-methyltransferase gene in a Japanese female population. Compr Psychiatry 2008;49:503507.

25. Cloninger CR. A unified biosocial theory of personality and its role in the development of anxiety states. Psychiatr Dev 1986;4:167-226.

26. Cloninger CR, Svrakic DM, Przybeck TR. A psychobiological model of temperament and character. Arch Gen Psychiatry 1993;50:975-990.

27. Cloninger CR. A systematic method for clinical description and classification of personality variants. A proposal. Arch Gen Psychiatry 1987; 44:573-588.

28. De Fruyt F, Van De Wiele L, Van Heeringen C. Cloninger's psychobiological model of temperament and character and the Five-Factor Model of personality. Pers Individ Dif 2000;29:441-452.

29. Kunisato Y, Yamaguchi A, Suzuki S. Cloninger's temperament and character model and the big five. JPN J Pers 2008;16:324-334.

30. Shimonaka Y, Nakazato K, Gondo Y, Takayama M. NEO-PI-R and NEOFFI Manual for the Japanese Version. Tokyo: Tokyo Shinri; 1999.

31. Samochowiec J, Syrek S, Michał P, Ryzewska-Wódecka A, Samochowiec A, Horodnicki J, et al. Polymorphisms in the serotonin transporter and monoamine oxidase A genes and their relationship to personality traits measured by the Temperament and Character Inventory and NEO Five-Factor Inventory in healthy volunteers. Neuropsychobiology 2004; 50:174-181.

32. Aoki J, Iwahashi K, Ishigooka J, Ikeda K. Association study on catecholO-methyltransferase (COMT) Val158Met gene polymorphism and NEOFFI. Psychiatry Res 2011;187:312-313.

33. Yoshimura K, Nakamura K, Ono Y, Sakurai A, Saito N, Mitani M, et al. Reliability and validity of a Japanese version of the NEO Five Factor Inventory (NEO-FFI): a population-based survey in Aomori prefecture. JPN J Stress Sci 1998;13:39-47.

34. Inoue K, Itoh K, Yoshida K, Higuchi H, Kamata M, Takahashi H, et al. No association of the G1287A polymorphism in the norepinephrine transporter gene and susceptibility to major depressive disorder in a Japanese population. Biol Pharm Bull 2007;30:1996-1998.

35. Yamamoto BK, Novotney S. Regulation of extracellular dopamine by the norepinephrine transporter. J Neurochem 1998;71:274-280.

36. Sesack SR, Hawrylak VA, Guido MA, Levey AI. Cellular and subcellular localization of the dopamine transporter in rat cortex. Adv Pharmacol 1998;42:171-174.

37. Carboni E, Silvagni A, Vacca C, Di Chiara G. Cumulative effect of norepinephrine and dopamine carrier blockade on extracellular dopamine increase in the nucleus accumbens shell, bed nucleus of stria terminalis and prefrontal cortex. J Neurochem 2006;96:473-481.

38. Bookman EB, Taylor RE, Adams-Campbell L, Kittles RA. DRD4 promoter SNPs and gender effects on Extraversion in African Americans. Mol Psychiatry 2002;7:786-789.

39. Eichhammer P, Sand PG, Stoertebecker P, Langguth B, Zowe M, Hajak G. Variation at the DRD4 promoter modulates extraversion in Caucasians. Mol Psychiatry 2005;10:520-522.

40. Golimbet VE, Alfimova MV, Gritsenko IK, Ebstein RP. Relationship between dopamine system genes and extraversion and novelty seeking. Neurosci Behav Physiol 2007;37:601-606.

41. Smillie LD, Cooper AJ, Proitsi P, Powell JF, Pickering AD. Variation in DRD2 dopamine gene predicts Extraverted personality. Neurosci Lett 2010;468:234-237.

42. Stein MB, Schork NJ, Gelernter J. A polymorphism of the $\beta 1$-adrenergic receptor is associated with low extraversion. Biol Psychiatry 2004;56: 217-224.

43. Miller GE, Cohen S, Rabin BS, Skoner DP, Doyle WJ. Personality and tonic cardiovascular, neuroendocrine, and immune parameters. Brain Behav Immun 1999;13:109-123.

44. Jonsson EG, Nothen MM, Gustavsson JP, Neidt H, Bunzel R, Propping $\mathrm{P}$, et al. Polymorphisms in the dopamine, serotonin, and norepinephrine transporter genes and their relationships to monoamine metabolite concentrations in CSF of healthy volunteers. Psychiatry Res 1998;79: 1-9.

45. Garvey MJ, Noyes R Jr, Cook B, Blum N. Preliminary confirmation of the proposed link between reward-dependence traits and norepinephrine. Psychiatry Res 1996;65:61-64. 